\title{
THE MEDIATION IN THE DOMESTIC VIOLENCE AS A WAY OF NON-JURISDICTIONAL CONFLICT RESOLUTION IN SPAIN
}

\author{
Dr. iur. José Antonio González-Costa, Spain
}

\begin{abstract}
The aim of this article is to expose, explain and examine the mediation in the domestic violence as a way to solve the problems without using the traditional methods as the court.

Many countries trust and use already the mediation as a methods to solve to conflicts between people and even in the personal relationship with positives results.

The EU, thought its Recommendation has adviced that the mediation it is a really good way that very country should use to sorted out the problems even when there is cases of domestic violence and family matters, reflecting that the society should have this tools to fix the problems without going always to the court.

In order to research the objective and fulfill tasks set the research project, the applied methods during the research progress are the following: historical research, analytical, inductive, logical, systemical. Also the method of the analysis of literature, the comparative legal method and theoretical method of research to investigate, analyse and summarize information of publications.

The methods chosen are very important in analysing the development of the differents resolutions of several international organizations and Conventions, that shows the way chosen throught the years about mediation.

The logical and analytical method was used in order to study content of the different countries laws and its experiences how to solved problems with the mediation.

The overall object of this article "The mediation in the domestic violence as a way non jurisdictional of resolution of conflicts" is to show that its possible to use another alternatives ways to solve the conflicts not just in the civil cases but also in criminal cases and specially in family.

The main conclusion shows that, the mediation is a very useful tool in order to solve and to fix conflicts in many spheres as civil,
\end{abstract}


business, family, in criminal cases, as in the violence domestic. The mediator must to have a training before starts the activities, like the specific program in Latvia for it. Thus, the E.U. is trying to convince the European states that the mediation as a method should be applied in every country helping the traditional ways to resolve conflicts.

Keywords: mediation, domestic violence, Criminal Law, conflicts settlement, mediation subjects.

\section{Introduction}

Without any doubts the mediation is becoming increasingly important as a means of resolving conflicts in many areas, as in civil, commercial, social and criminal matters. To this last, the criminal law, we will refer in this article, valuing whether it is possible to go to the mediation in the criminal jurisdiction in matters of domestic violence or if is not possible to use mediation to solve the problems that are generated with this type of violence.

The physical or psychic aggression occurs when communication channels fail and mutual understanding is not possible. Both physical and psychic aggression represent an evil act, an attack against the person in his condition of human, against his personal integrity and against his freedom. Aggression is used as a means of subjugation to the victim, in such a way that making this violence, in the victim is generated a positive reaction to the demands of the aggressor, doing what the aggressor demands. The aggressions occur from the subject more strong to the weaker, regardless of their sex. Statistically man tends to use more physical violence and a woman more psychic.

As we know, mediation in cases of domestic or gender violence is banned in many countries of the European Union, so it should be wondered whether this prohibition is right and even if it is necessary.

The answer by the European doctrine and the judges themselves has been unanimous, in which I include myself, in the sense of favouring the general implantation of mediation in the criminal sphere, as a method of resolving disputes between individuals, out of the ordinary way as is that of the courts of justice. 


\section{Mediation in domestic violence}

Domestic and gender violence is a problem that encompasses and integrates the family, their interpersonal relationships and the human being in the foreground, leaving the legal aspects in the back ground.

Likewise, the courts are full with criminalization of domestic quarrels that are lacking in penal relevance, which may be solved by alternative ways such as mediation to resolve personal conflicts in the area of the couple or domestic without go to court and at the same time, relieve the courts, filtering in part the cases that are relevant from the criminal point of view.

Mediation has many advantages, as are more personal and direct treatment than a court and can be employed at any judicial stage, before during and after the trial ${ }^{1}$. As the main feature of mediation is the voluntary of it, that means, the parties must agree to mediation to resolve their conflict.

The use of mediation is a very important tool against any conflict and of course domestic violence, because it helps to calm the mood between the parties, it can be developing in several sessions, being able to managed the problems from a more personal point of view to get a solution, that is reflected in a agreement between the parties.

Also the mediator can be helped by other professionals, such as psychologists, psychiatrists and social workers, who provide solutions to the conflict from several points of view and educate and advise the parties in the personal field, to try that the violent acts not been repeated.

On the other hand, the courts of justice do not usually have these advantages, as we know the court try to put some measures to avoid repeat the violent facts and judge whether there has been any aggression and if such conduct is punishable and subsequently, proceed to impose a penalty.

So, there is no doubt that mediation is a more fast, personal approach and that has other ways to solving domestic violence problems.

As an example, in the case of divorces the parties may go to mediation when there has been no violence and both agree to submit to it. Unfortunately there is no culture of mediation as a method of resolution of conflicts, because traditionally it is attended to the court, often not only to discuss the conditions of divorce but also to try to 
make the spouses the most damage possible each other. However the advantage of mediation is that if you can enter the personal field, not the traditional method as are the courts, and also mediation can come to know the matter at any time.

However, the mediation is criticized because its characteristic of the voluntary in its application, it is difficult, often, that the parties agree even for it or to appoint a mediator.

Another criticism is that the measurement cannot establish any penalty, as a method of punishment for illicit conduct or deterrence, and tends to think that the agreements reached by the parties are easily broken and that there is also no ways coercive to oblige their fulfillment.

The judges have noticed this problem and in many cases are the main advocates of mediation ${ }^{2}$, defending the reduction of the litigiousness that has two main characteristics, the first one, that the litigation must be the "last ratio" of any conflict of interests and second, the litigiousness is clearly oversized and has a high cost: With this attitude we want to follow the guidelines or strategic lines marked by the Council of Europe in 2007 for its achievement and grouped under three major topics "availability, accessibility and awareness" problems that try to be solved through mediation.

Often the psychic or physical aggressions appear by a conjugal crisis and it is shown that statistically the greater number of cases of violence against the woman occurs during the coexistence, in the time of dating and even intimes very after the process of divorce.

However, I believe that there are cases when mediation has no place, or only after the judicial intervention as a repairing medium, which are in serious or very serious cases with physical or psychic aggression in situations of imbalance of power.

The Council of Europe on family mediation, by means of its recommendation ${ }^{3}$, states that the mediator will pay special attention to whether there has been violence between the parties or whether it can occur in the future, as well as the effects it may have on the situation of the parties to the negotiation and to examine whether, in these circumstances, the mediation process is appropriate.

In relation to other countries, Spain, has a slight delay in the application of mediation, seeing in the practice of the society of those countries where mediation is applied, an improvement in the resolution, are not so saturated the courts and has created a 
consciousness a gradual of conflict resolution by non-legal means.

In countries such as Austria, the UK or Norway, many problems are solved, using mediation quite successfully. In other countries such as Spain, Germany or Italy should take note, in order to implement this new model, in which legal operators will take part in the gender violence procedure with evaluations, meetings and sessions with those involved, that would undoubtedly result in a notable decrease in cases of gender violence, by gradually educating society, contributing in the same way in the decongestion of the courts of violence, which will know practically the serious cases or very serious.

A big part of the doctrine, argues that mediation has a place in domestic violence and for example Jefimovs ${ }^{4}$ defends the implementation of mediation for any type of criminal dispute, also covering domestic violence.

Arangüena Fanego ${ }^{5}$ says it is essential that mediation is not essential to resolve conflicts of gender violence, making it a caveat and here I agree fully with the author ${ }^{6}$, in that only for cases where the facts are of slight entity, sporadic or occasional and in short those that are little serious.

Barona Vilar ${ }^{7}$, meanwhile defends the mediation in the field of gender violence, as an extrajudicial procedure in which both parties victim and aggressor voluntarily, undergo mediation as a means that solve their criminal conflict, proceeding to the reparation of the damage, the satisfaction of the victim and the fulfillment of the penalty imposed on the offender, indirectly benefiting the state to a much cheaper and fast way ${ }^{8}$.

In Spain the majority of the doctrine defends there vision of the law of violence in this sense being its application in both civil and penal fields.

On the other hand, Salvador Concepción, calls for a legislative homogenization at European level in which it has the same regulation, procedure and penalties and in which mediation plays an important role as and all this through a legislative directive, making Reference to the text of the Council of Europe Convention on the Prevention and control of violence against women and domestic violence.

On the other hand, Salvador Concepción ${ }^{9}$, calls for a legislative homogenization at European level in which it has the same regulation, procedure and penalties and in which mediation plays an important 
role as and all this through a legislative directive, making Reference to the text of the Council of Europe Convention on the Prevention and control of violence against women and domestic violence.

In addition, the European Parliament and the Council on the European Protection Order which, in any Member State which is mentioned as a state of execution, have advanced with the adoption of the Directive 2011/99/UE of 13 December, an order of protection issued by another Member State-referred to as the issuing statecould be asserted without the need to initiate a new procedure for the execution and effectiveness of that order. Also the Directive 2011/36/UE of the European Parliament and of the Council on the Prevention and fight against the trafficking of human beings and the protection of the victims which, being circumscribed to the scope of the trafficking of human beings, typifies the infringements Related to this issue by establishing the minimum penalties that States will have to impose on the perpetrators, as well as regulating various issues such as their sanctioning regime or the measures of support and assistance for the victims. It concludes by leaving the door open both to mediation and to other means that try to homogenize and combine criteria in terms of gender violence.

We cannot forget that the mediator must be trained, have specific knowledge in law and have additional training in other fields, as is the case of Latvia and its "intermediation training program" for mediators ${ }^{10}$.

\section{Conclusions}

It is clear the need of mediation in domestic or gender violence to play a more relevant role, not only to address civilian issues but also criminal matters, but with the proviso that in the penal field it is in the case of mild cases in occasional assumptions and that are of little entity, since outside of these cases the problem of root could not be tackled, as is in the case of inequality, since such inequality avoids the dialogue and the consensus between both sides of real form. Mediation is an indispensable tool that helps to solve the problems, from a personal point of view being able to discover what are the causes that originate it and to proceed to propose ways for its solution. It also has the advantage that educative methods or measures for those involved in violent acts can be agreed not to happen again and 
that in many cases they are due to a lack of education and culture in equality and mutual respect and consideration.

This is why, it is essential that mediation be supported by professionals, such as psychologists, social workers and psychiatrists who will rectify violent behaviors and educate in equality, based on dialogue as a way of solving problems.

The countries where mediation cannot be applied are the most conflicting and the most relapsing precisely because it prohibits such a personal and useful method as mediation, preventing access to other avenues of conflict resolution other than the traditional judicial.

It is essential for the mediation success that mediators receive specific training in order to provide solutions between the parties to the conflict.

\section{References}

1 See Nikolajs Jefimovs, in his article "Valuations of security measures: The peculiarities of the application of mediation in the area of resolving criminal legal conflicts". Journal of Security and Sustainability Issues. ISSN 20297017. 2018, volume 8, number 1 .

2 For example, GEMME (European Group of Magistrates for Mediation), in which there are currently more than 100judges and associate magistrates and other persons, juristsor professionals relevant to the world of mediation. On the CGPJ website there is a public and free-access thematic area, which can be consulted by any citizen, on this subject with the map of the courts from which family mediation services are offered.

3 ion No. (98) 1 of the Council of Europe onfamily mediation in paragraph 3.9.

4 See Nikolajs Jefimovs, 2017, "Towards conflicts'settlement: development of the meaning of mediation in the legal doctrine". Journal of Security and Sustainability Issues, 6(4):665-672. http://doi.org/10.9770/jssi.2017.6.4 (11).

5 See chapter II of "Preventive measures for the resolution of disputes in criminal matters." Criminal mediation in the field of gender violence has the time come to consider its prohibition? P. 145-162. Work carried out in the March of the research project of the national R + D + I Plan of the Ministry of Economy and Competitiveness (DER 2012-31549). The status of the victim. Proposals for the incorporation of European Union regulations.

6 See in its Article Penal Law magazine, ISSN 1576-9763, n ${ }^{\circ} .26,2009$, pp. $20-$ 21 Criminal Law Magazine, ISSN 1576-9763, $\mathrm{n}^{\circ} .26,2009$, Editorial VLex, Valencia.

7 Baron Vilar S. Penal Law Journal, ISSN 1576-9763, nº. 26,2009, pp. 25 and SS, Editorial VLex, Madrid. 
8 Thus, Barona Vilar, S., "Criminal mediation as part of the system of penal guardianship in the 21 st century. One more step towards resocialization and restorative justice", in Criminal Law magazine, No. 26, January 2009, 11-53 and, of the same author, criminal mediation. Ed. Foundation, Ines and juridical regime, Valencia, 2011.

9 See Salvador Concepción R., Gender violence in Spain United Kingdom, France and Italy a global concept? P.136-161. Editorial Dyckinson, Madrid 2015.

10 See Nikolajs Jefimovs, in his article "Evaluations of security measures: The peculiarities of the application of mediation in the area of resolving criminal legal conflicts". Journal of Security and Sustainability Issues. ISSN 20297017. 2018, volume 8, number 1 .

\section{Anotācija}

Raksta "Mediācija lietās par vardarbību ǵimenē kā konflikta ārpustiesas risinājuma veids Spānijā̄" mērķis ir iepazīstināt lasītāju ar jaunu pieeju konfliktu, kas saistīti ar vardarbību gímenē, noregulēšanu ārpus tradicionālai lietas izskatīšanai tiesā, proti, pielietojot mediācijas metodi. Mediācija tiek samērā plaši izmantota arī civiltiesisko strīdu atrisināšanā uzñēmējdarbībā un citās jomās. Secināts, ka Eiropas Savienības valstīs mediācija jūtami atvieglo tiesu darbu, pieaug konflikta dalībnieku uzticēšanās šai inovatīvajai pieejai. 